\title{
INFLUENCE OF ORDER OF LACTATION ON MILK PRODUCTION AND SOMATIC CELL COUNT IN ALPINE GOATS
}

\author{
N. Memiši ${ }^{1}$, V. Bogdanović ${ }^{2}$, M. Žujović ${ }^{3}, Z$. Tomić ${ }^{3}$ \\ ${ }^{1}$ AD "Mlekara", Tolminska 10, 24000 Subotica, Republic of Serbia \\ ${ }^{2}$ Faculty of Agriculture, Nemanjina 6, 11080 Belgrade-Zemun, Republic of Serbia \\ ${ }^{3}$ Institute for Animal Husbandry, Autoput 16, 11080 Belgrade-Zemun, Republic of Serbia \\ Corresponding author: memisin@mlekara.rs \\ Original scientific paper
}

\begin{abstract}
In this paper, the annual results of the effect of lactation on milk production, the contents of some chemical parameters in the milk (milk fat, protein and dry matter without fat) and somatic cells in milk goat breeds Alpino in intensive production during one production year. Control is included a total of 82 French Alpine goats in different lactations (first-16 heads, the second-19 heads, 29 heads the third-and fourth and subsequent lactation together-18 heads).). Somatic cell count and chemical quality of milk is controlled on a daily basis in the laboratory for raw milk AD "Dairies" - Subotica on the machine CombiFoss FC 6200. The variability of the analyzed characteristics is presented descriptive parameters and the effect of lactation is determined by a factorial analysis of variance. The average value for somewhat milk goats for the treated population was $362.83 \mathrm{~kg}$, with average milk fat content of $3.31 \%$. Analysis of variance confirmed that the differences that were established under the influence of lactation for all traits analyzed, except for percentage of milk fat, were significant at $\mathrm{P}<0.01$
\end{abstract}

Key words: alpine goat, lactation, somatic cell, composition of milk

\section{Introduction}

Milk performance is polygenic property caused by numerous genes which directly or indirectly have impact on its expression. Production of milk is closely associated with environment factors, such as: nutrition of mothers/dams before and after partus, number of kids, climatic and soil conditions, housing and care, and many other factors. High standard of milk hygiene is required for the purpose of human health protection, maintenance of natrual biological value of raw materials and ensuring of corect technological processes in the processing of milk. 
Somatic cell count in milk sample is indicator of udder health and incidence of clicnical and sub-clinical mastitis in the herd of dairy goats. Monitoring and determination of the somatic cell count is very important factor in evaluation of the quality of milk delivered to dairy plant, and it is used, among other parameters, such as chemical composition of milk (milk fat and protein) and total plate, for determination of the price of milk (Dankov et al., 2003). Also, somatic cell count can be excellent indicator in the mastitis monitoring programs.

Increased somatic cell count is associated with decrease of milk quantity and changes in its composition, which can afec its sutiability for processing. Inflammatory process in mammary gland, ocuring as the consequence of the action of pathogen microorganisms, toxins or tissue damage, leads to changes in milk secretion, which results in quantitative and qualitative changes in milk (Katić et al., 1994; Heeschen, 1995; Bernacka, 2006). These changes relate to icnrease of somatic cell count, increase of albumin content in the milk serum, reduction of the secretion of milk components (casein, fat, lactose) and reduction of the quantity of milk. Also, these changes lead to reduction of the milk's thermal stability, longer time for milk coagulation and decrease in milk sustainability/shelf life. Based on above mentioned, it can be concluded with certainty that increase somatic cell count in milk affects its suitability for processing (Auldist and Hubble, 1998). Compared to cow milk, goat milk in average has higher somatic cell count which often amounts to several millions (Danków et al., 2003).

Taking this into consideration, objective of this paper was to analyse the effect of order of lactation on yield, chemical composition and somatic cell count in goat milk.

\section{Materials and Methods}

Research was done on goat farm located in the vicinity of municipality of Subotica. Total of 82 heads of Alpine breed goats were included in the control of yield, chemical composition of milk and somatic cell count, in different lactations (the first lactation - 16 animals, the second lactation- 19 animals, the third lactation - 29 animals and fourth and subsequent lactations together - 18 animals). The quantity of produced milk in all goats was determined on the $10^{\text {th }}$ day after partus at the latest, all through to the end of lactation (dry off). All animals were in A control. Milking of goats was mechanized, and carried out in modern milking parlour for goats manufactured by company „Sac“, and control of milk yield was done twice in equal time intervals ( 7 a.m. and 7 p.m.), and in intervals of 28-32 days. Measuring of milked amount of milk was done using graduated cylinders, the smallest division of $10 \mathrm{ml}$.

Composition of milk (quantity of milk fat, proteins and fat free dry matter FFDM) was determined by the method of infra-red spectrophotometry using the 
apparatus Milkoscan FT 6200, whereas the total somatic cell count (SCC) in milk was determined by fluoro-opto-electronic method on apparatus Fossomatic FC. In order to approach the normal distribution, a logarithm transformation of the somatic cell count was done and new trait was obtained (SCC log).

Goats were housed in closed facilities, and the method of stable feeding was applied. Goats had access to sufficient quantities of alfalfa hay as well as $1 \mathrm{~kg}$ of concentrate mixture which was administered twice a day. Chemical composition of used concentrate is presented in Table 1 .

Table 1. Chemical composition of concentrate mixture used in goat nutrition

\begin{tabular}{|l|c|}
\hline Feed & $\begin{array}{c}\text { Share in } \\
\text { mixture, } \%\end{array}$ \\
\hline Corn cracked & 64,50 \\
\hline Wheat bran & 12,00 \\
\hline Soybean meal (44\%) & 5,00 \\
\hline Sunflower meal (33\%) & 16,00 \\
\hline Di-calcium phosphate (16\%P) & 1,00 \\
\hline Premix & 0,5 \\
\hline Salt, iodinated, g & 1,0 \\
\hline Dry matter, \% & 85.7 \\
NEL MJ/kg & 6,54 \\
CP/g & 14,5 \\
\hline
\end{tabular}

Variability of analysed properties was determined by method of descriptive statistics, whereas the effect of order of lactation was determined by one factor variance analysis.

\section{Results and Discussion}

In Table 2, average values and variability of production of milk, content of certain milk components and somatic cell count are presented. 
Table 2. Average values and variability of milk yield, chemical composition and somatic cell count

\begin{tabular}{|l|c|c|c|c|c|}
\hline Variable & $\mathrm{N}$ & $\mathrm{x}$ & Minimum & Maximum & $\mathrm{SD}$ \\
\hline $\begin{array}{l}\text { Duration of } \\
\text { lactation }\end{array}$ & 82 & 252.41 & 202.00 & 302.00 & 18.27 \\
\hline Milk yield & 82 & 362.83 & 240.30 & 468.90 & 52.71 \\
\hline Daily milk yield & 82 & 1.43 & 1.07 & 1.72 & 0.15 \\
\hline MF & 82 & 3.32 & 2.82 & 3.62 & 0.21 \\
\hline \% Proteins & 82 & 2.93 & 2.64 & 3.19 & 0.15 \\
\hline FFDM & 82 & 7.94 & 7.60 & 8.36 & 0.16 \\
\hline SCC & 82 & $1,259,682.93$ & $724,000.00$ & $1,865,000.00$ & $272,951.13$ \\
\hline SCC, $\log$ & 82 & 20.23 & 19.47 & 20.83 & 0.33 \\
\hline
\end{tabular}

MF - Milk fat; FFDM - fat free dry matter; SCC - somatic cell count

Average value for total quantity of milk in investigated population was 362,83 $\mathrm{kg}$, whereas the somatic cell count for entire lactation period in average was $1.26 \times 10^{3}$. Compared to results obtained by other authors, duration of lactation in our research is similar to the level reported by Gall (1980) for duration of lactation in French Alpine breed from 200 to 300 days, as well as Kompan et al. (1998) for lactation of 258 days for same goat breed. Lower values were stated by Pavliček et al. (2006) in alpine goats reared in the private sector and whose lactation duration was from 201 to 203 days. Total quantity of milk for goats in the first lactation was the lowest $(297.8 \mathrm{~kg})$, and in later lactation it increased, so in the fourth and later lactations it reached $382,6 \mathrm{~kg}$. Average value of total milk quantity of goats in the first lactation was lower by $84,8 \mathrm{~kg}$, compared to established value in older goats (the fourth lactation). Data on average production values, chemical composition and somatic cell count in alpine goats, depending on the order of lactation, is presented in Tables 3 and 4 .

Table 3. Analysis of milk traits depending on the order of lactation

\begin{tabular}{|c|c|c|c|c|c|c|c|}
\hline \multirow{2}{*}{ Lactation } & \multirow{2}{*}{$\mathrm{N}$} & \multicolumn{2}{|c|}{$\begin{array}{c}\text { Duration of } \\
\text { lactation }\end{array}$} & \multicolumn{2}{c|}{ Milk yield } & \multicolumn{2}{c|}{$\begin{array}{c}\text { Average daily } \\
\text { milk yield, } \mathrm{kg}\end{array}$} \\
\cline { 3 - 8 } & & $\mathrm{x}$ & $\mathrm{SD}$ & $\mathrm{X}$ & $\mathrm{SD}$ & $\mathrm{x}$ & $\mathrm{SD}$ \\
\hline L1 & 16 & 239.37 & 15.04 & 297.8 & 29.09 & 1.24 & 0.10 \\
\hline L2 & 19 & 252.57 & 16.13 & 354.8 & 31.23 & 1.40 & 0.10 \\
\hline L3 & 29 & 260.51 & 18.99 & 391.5 & 47.97 & 1.49 & 0.10 \\
\hline L4 & 18 & 250.77 & 15.70 & 382.6 & 42.30 & 1.52 & 0.13 \\
\hline Average & 82 & 252.41 & 18.27 & 362.8 & 52.70 & 1.43 & 0.15 \\
\hline
\end{tabular}

Antunac (1994) also established that goats in the first lactation have the lowest milk production/yield (359 1), whereas the highest production was recorded for 
goats in the third lactation (588 1). Similar increase in milk production in goats in subsequent lactations was established by Margetin and Milerski (2000). Finley et al., (1984.) in their research carried out on three goat breeds (Alpine, Saanen, Toggenburg) in USA, established the highest production of milk in goats at the age between 24 and 50 months. Considering the results of the analysis of the milk fat content in milk from Alpine breed goats, it was determined that the average value for investigated population was $3,31 \%$. Established mean value for milk fat content was the highest in case of goats in the first lactation $(3,4 \%)$ and it decreased in subsequent lactations, so in the fourth lactation it was $3.24 \%$, however, the differences were not statistically significant $(\mathrm{P}>0,05)$.

Order of lactation, like in previous examples, influenced also the content of other milk parameters, e.g. protein percentage and fat free dry matter. Content of proteins in milk decreased from the first lactation $(3,04 \%)$ to the third $(2,85 \%)$, but in the fourth and later lactations this value was slightly higher compared to goats in the third lactation $(2.92 \%)$. Somatic cell count was the lowest in milk obtained from goats in the first lactation $\left(1.02 \times 10^{3}\right)$ and it increased in later lactations. Somatic cell count in the second and the third lactation was $1.11 \times 10^{3}$ and $1.36 \times 10^{3}$ whereas in the fourth and later lactations it was the highest with average value of $1.42 \times 10^{3}$.

Table 4. Analysis of the traits of chemical composition and somatic cell count (SCC, log) depending on the order of lactation

\begin{tabular}{|c|c|c|c|c|c|c|c|c|c|}
\hline \multirow{2}{*}{ Lactation } & \multirow{2}{*}{$\mathrm{N}$} & \multicolumn{2}{|c|}{ Milk fat, \% } & \multicolumn{2}{|c|}{ Protein, $\%$} & \multicolumn{2}{c|}{$\begin{array}{c}\text { Fat free dry } \\
\text { matter, \% }\end{array}$} & \multicolumn{2}{c|}{ SCC, log } \\
\cline { 3 - 11 } & & $\mathrm{x}$ & $\mathrm{SD}$ & $\mathrm{x}$ & $\mathrm{SD}$ & $\mathrm{x}$ & $\mathrm{SD}$ & $\mathrm{x}$ & $\mathrm{SD}$ \\
\hline L1 & 16 & 3.40 & 0.12 & 3.04 & 0.11 & 8.04 & 0.16 & 19.93 & 0.33 \\
\hline L2 & 19 & 3.29 & 0.17 & 2.96 & 0.12 & 7.98 & 0.16 & 20.10 & 0.26 \\
\hline L3 & 29 & 3.33 & 0.25 & 2.85 & 0.14 & 7.87 & 0.13 & 20.36 & 0.24 \\
\hline L4 & 18 & 3.24 & 0.22 & 2.92 & 0.14 & 7.90 & 0.11 & 20.41 & 0.28 \\
\hline Average & 82 & 3.31 & 0.21 & 2.93 & 0.14 & 7.94 & 0.15 & 20.22 & 0.33 \\
\hline
\end{tabular}

Similar values in regard to somatic cell count in goat milk, depending on the order of lactation, were reported by Raynal-Ljutovac et al. (2006). Kozačinski et al. (2002) established in goat milk average SCC of $1.300 .000 / \mathrm{ml}$ and concluded that the limit for SCC in goat milk can be over $1.000 .000 / \mathrm{ml}$, which is in accordance with results obtained in this study. Increased SCC in milk from dairy goat breeds reared in the USA is often, and above $1.000 .000 / \mathrm{ml}$ as stated by Haenlein (2002). Similar values, even slightly higher for SCC, depending on the order of lactation are stated by Pavliček et al. (2006) in Alpine breed goats. Higher SCC in goat milk $(1.589 .000 / \mathrm{ml})$ was also established by Ying et al. (2002.). Antunac et al. (1997) stated that herds of dairy goats rarely have in the average milk sample SCC below one million. 
Tabele 5. The effect of order of lactation on trait variability

\begin{tabular}{|l|c|c|c|c|c|c|c|c|}
\hline \multicolumn{1}{|c|}{ Variable } & $\begin{array}{c}\text { Sum of } \\
\text { the model } \\
\text { square }\end{array}$ & $\begin{array}{c}\text { Degree of } \\
\text { freedom in } \\
\text { the model }\end{array}$ & $\begin{array}{c}\text { Model } \\
\text { square } \\
\text { mean }\end{array}$ & $\begin{array}{c}\text { Sum of } \\
\text { the error } \\
\text { square }\end{array}$ & $\begin{array}{c}\text { Degree of } \\
\text { the } \\
\text { freedom } \\
\text { of error }\end{array}$ & $\begin{array}{c}\text { Error } \\
\text { square } \\
\text { mean }\end{array}$ & F & P \\
\hline $\begin{array}{l}\text { Lactation } \\
\text { duration }\end{array}$ & 4.67 & 3 & 1.55 & 2.23 & 78 & 2.86 & 5.42 & 0.001 \\
\hline Milk yield & 9.98 & 3 & 3.32 & 1.25 & 78 & 1.60 & 20.75 & 0.00 \\
\hline Daily milk yield & 8.68 & 3 & 2.89 & 9.65 & 78 & 1.23 & 23.39 & 0.00 \\
\hline MF, \% & 2.32 & 3 & 7.74 & 3.37 & 78 & 4.32 & 1.79 & 0.15 \\
\hline \% Proteins & 3.92 & 3 & 1.30 & 1.42 & 78 & 1.82 & 7.17 & 0.00 \\
\hline FFDM & 3.78 & 3 & 1.26 & 1.65 & 78 & 2.12 & 5.92 & 0.001 \\
\hline SCC & 1.90 & 3 & 6.36 & 4.12 & 78 & 5.28 & 12.02 & 0.00 \\
\hline SCC, $\log$ & 2.80 & 3 & 9.35 & 6.08 & 78 & 7.80 & 11.98 & 0.00 \\
\hline
\end{tabular}

MF - milk fat; FFDM - fat free dry matter

Significance: $* * * \mathrm{P}<0.01$.

Differences established under the influence of order of lactation for all analysed traits, with the exception of milk fat, were significant at the level of $\mathrm{P}<0.01$

\section{Conclusion}

Based on results obtained in the study of the effect of order of lactation on production of milk/yield, content of certain chemical parameters in milk (milk fat, proteins and fat free dry matter) and somatic cell count in milk obtained from alpine breed goats in intensive production, the following can be concluded:

Goats in the first lactation produced less milk $(297.8 \mathrm{~kg})$ compared to those in the second $(354.8 \mathrm{~kg})$, the third $(391.5 \mathrm{~kg})$ and the fourth and later lactations $(382.6 \mathrm{~kg})$.

The highest content of milk fat, proteins and fat free dry matter was recorded for goats in the first lactation, and the percentage decreased from the first to later lactations.

Somatic cell count was the lowest in milk obtained from goats in the first lactation $\left(1.02 \times 10^{3}\right)$ and it increased in later lactations. So, the somatic cell count in the second and the third lactation was $1.11 \times 10^{3}$ and $1.36 \times 10^{3}$, whereas in the fourth and later lactations it was the highest, the average value was $1.42 \times 10^{3}$.

Results of the variance analysis confirm that the differences established under the influence of order of lactation for all analysed traits, with the exception of milk fat content, were significant at the level of $\mathrm{P}<0.01$. 


\title{
Acknowledgment
}

Research was financed by the Ministry of Education and Science Republic of Serbia, project TR 31053.

\section{Uticaj laktacije po redu na proizvodnju mleka i broj somatskih ćelija koza alpina rase}

\author{
N. Memiši, V. Bogdanović, M. Žujović, Z. Tomić
}

\section{Rezime}

U ovom radu prikazani su rezultati ispitivanja uticaja laktacije po redu na proizvodnju mleka, sadržaj mlečne masti, proteina i suve materije bez masti i broj somatskih ćelija u mleku koza francuske rase Alpina u intenzivnoj proizvodnji u toku jedne proizvodne godine. Kontrolom je obuhvaćeno ukupno 82 grla u različitim laktacijama (prva - 16 grla, druga - 19 grla, treća - 29 grla, a četvrta i naredne latkacije zajedno - 18 grla).

Broj somatskih ćelija, kao i hemijski kvalitet mleka, kontrolisan je svakodnevno u laboratoriji za sirovo mleko AD "Mlekare" - Subotica na aparatu CombiFoss 6200 FC. Varijabilnost analiziranih osobina je prikazana parametrima deskriptivne statistike, a uticaj laktacije po redu je utvrđen jednofaktorijalnom analizom varijanse.

Prosečna vrednost za ukupnu količnu mleka kod ispitivane populacije koza iznosila je $362,83 \mathrm{~kg}$, sa prosečnim sadržajem mlečne masti od 3,31\%. Rezultati analize varijanse potvrđuju da su razlike koje su ustanovljene pod uticajem laktacije po redu za sve analizirane osobine, izuzev za procenat mlečne masti, bile značajne na nivou $\mathrm{P}<0.01$

\section{References}

AULDIST M.J., HUBBLE I.B. (1998): Effect of mastitis on raw milk and dairy products, Australian Journal of Dairy Technology, 53, 28-36.

ANTUNAC N. (1994.): Povezanost sastava i količine mlijeka s redoslijedom laktacija alpina i sanskih koza u velikim stadima. Disertacija. Agronomski fakultet. Sveučilište u Zagrebu.

ANTUNAC N., HAVRANEK J., SAMARDŽIJA D. (1997): Somatske stanice u kozjem mlijeku. Mljekarstvo, 47, 2, 123-124. 
BERNACKA H ( 2006): Cytological quality of goat milk on the basis of the somatic cell count. Journal of Central European Agriculture, 7, 4, 773-778.

DANKOW R., CAIS-SOKOLINSKA D., PIKUL J., WOJTOWSKI J. (2003): „Jakość cytologiczna mleka koziego”, Med. Wet., 59, 1, 77-80.

FINLEY C.M., THOMPSON J.R., BRADFORD G.E. (1984): Age-parityseason adjustment factors for milk and fat yields of dairy goats. J. Dairy Sci., 67, 18681872 .

GALL C. (1980): Relationship between body conformatiion and production in dairy goats. Journal of Dairy science, 63, 10.

HEESCHEN W.H. (1995): Mastitis: The disease under aspects of milk qualityand hygiene.Kieler Milchwirtschaftiliche Forschungsberichte, 47, 3, 221-237.

HAENLEIN G.F.W. (2002): Relationship of somatic cell counts in goat milk to mastitis and productivity. Small Ruminant Research, 45, 163-178.

KATIĆ V., EL HUDA T., BABIĆ LJ., POPOVIĆ J. (1994): Uticaj mastitisa na kvalitet mleka. Veterinarski glasnik, 16, 271-276.

KOMPAN D., BREŽNIK S., BIRTIĆ D., DROBNIĆ M. (1998): Production and composition of sheep and goat milk in Slovenia. 6 th International Symposium «Animal Science Days», Portorož, 16 -18 September, Slovenia.

KOZAČINSKI L., MAJIĆ T., CVRTILA Ž., HADŽIOSMANOVIĆ M. (2002): Istraživanje i značenje broja somatskih stanica u kozjem mlijeku. Mljekarstvo, 51, 2, 81-90.

MARGETIN M., MILESKI M. (2000): The effect of nongenetic factors on milk yield and composition in goats of white short-haired breed. Czech Journal of Animal Science, 45, 501-509.

PAVLIČEK J., ANTUNOVIĆ Z., SENČIĆ Đ., ŠPERANDA M. (2006): Proizvodnja i hemijski sastav kozijeg mlijeka u zovisnosti od redoslijda i stadiju laktacije. Poljoprivreda, 12, 2, 52-57.

RAYNAL-LJUTOVAC K., PIRISI A., DE CREMOUX R., GONZALO C. (2006): Somatic cells of goat and sheep milk: Analytical, sanitary, productive and technological aspects. Small Ruminant Research, in press.

YING C., WANG H.T., HSU J.T. (2002): Relationship of somatic cell count, physical, chemical and enzymatic properties to the bacterial standard plate count in dairy goat milk. Livestock Production Science, 74, 63-77. 